\title{
Microbiological and Physicochemical Characteristics of Iyi-Nna Stream, Umuariaga, Ikwano L.G.A, Abia State, Nigeria.
}

\author{
${ }^{1}$ Eze, Vincent Chukwuemeka, ${ }^{2}$ Edward, Kelechi Chiamaka and \\ ${ }^{3}$ Shedrack, Ijeoma Florence \\ Department of Microbiology, Michael Okpara University of Agriculture, Umudike, Abia State, Nigeria.
}

\begin{abstract}
The microbiological and physicochemical characteristics of Iyi-nna stream were carried out. A total of 20 water samples were collected and analyzed for total aerobic plate count, coliform count, Escherichia coli count, Salmonella-Shigella count, Vibrio cholerae count and fungal count using pour plate technique. The media used were nutrient agar, MacConkey agar, eosin methylene blue agar, Salmonella-Shigella agar, thiosulphate citrate bile sucrose agar and potato dextrose agar. The statistical analyses used were analysis of variance and standard deviation. The total aerobic plate count range from $1.5 \pm 0.2 \times 10^{6} \mathrm{cfu} / \mathrm{mL}$ to $1.12 \pm 0.5 \times$ $10^{7} \mathrm{cfu} / \mathrm{mL}$; coliform count ranged from $0 \pm 0.0 \mathrm{MPN} / 100 \mathrm{~mL}$ to $902 \pm 20 \mathrm{MPN} / 100 \mathrm{~mL}$; Salmonella-Shigella count ranged from $0 \pm 0.0 \mathrm{cfu} / \mathrm{mL}$ to $7 \pm 0.4 \times 10^{3} \mathrm{cfu} / \mathrm{mL}$; Escherichia coli count ranged from $0 \pm 0.0 \mathrm{cfu} / \mathrm{mL}$ to $2.4 \pm 0.6 \times 10^{3} \mathrm{cfu} / \mathrm{mL}$; Vibrio cholerae count ranged from $0 \pm 0.0 \mathrm{cfu} / \mathrm{mL}$ to $6 \pm 0.5 \times 10^{2} \mathrm{cfu} / \mathrm{mL}$ and the fungal count ranged from $0 \pm 0.0 \mathrm{cfu} / \mathrm{mL}$ to $2.5 \pm 0.07 \times 10^{2} \mathrm{cfu} / \mathrm{mL}$. The microorganisms isolated and their percentage occurrence were Pseudomonas species, Vibrio cholerae, Shigella species, Staphylococcus aureus, Salmonella species, Bacillus species, Proteus species, Escherichia coli, Enterobacter species, Aspergillus species, Penicillum species and Yeast. The mean values ranged as follows, $p H, 6.15 \pm 0.1-6.90 \pm 0.2$; temperature, $29.0 \pm .02^{\circ} \mathrm{C}-31.0 \pm 0.05^{\circ} \mathrm{C}$; total dissolved solids, $0.024 \pm 0.002 \mathrm{mg} / \mathrm{L}-0.11 \pm 0.01 \mathrm{mg} / \mathrm{L}$; total suspended solids, $0.015 \pm 0.001 \mathrm{mg} / L-0.034 \pm 0.003 \mathrm{mg} / L$; alkalinity, $0.07 \pm 0.01 \mathrm{mg} / \mathrm{L}-0.36 \pm 0.03 \mathrm{mg} / \mathrm{L}$; hardness, 42.75 $\pm 2.5 \mathrm{mg} / \mathrm{L}-94.85 \pm 10.0 \mathrm{mg} / \mathrm{L}$; nitrate, $0 \pm 0.0 \mathrm{mg} / \mathrm{L}-65.47 \pm 5.0 \mathrm{mg} / \mathrm{L} ;$ sulphate, $0 \pm 0.0 \mathrm{mg} / \mathrm{L}-332.35 \pm$ $25.0 \mathrm{mg} / \mathrm{L}$; phosphate, $8.70 \pm 1.0 \mathrm{mg} / \mathrm{L}-86.82 \pm 7.5 \mathrm{mg} / \mathrm{L}$; zinc, $0.24 \pm 0.02 \mathrm{mg} / \mathrm{L}-1.88 \pm 0.3 \mathrm{mg} / \mathrm{L}$; iron, $0.86 \pm$ $0.01 \mathrm{mg} / \mathrm{L}-3.54 \pm 0.05 \mathrm{mg} / \mathrm{L}$; copper, $0 \pm 0.0 \mathrm{mg} / \mathrm{L}-0.4 \pm 0.01 \mathrm{mg} / \mathrm{L}$; silver, $0 \pm 0.0 \mathrm{mg} / \mathrm{L}$; lead, $0 \pm 0.0 \mathrm{mg} / \mathrm{L}-$ $0.8 \pm 0.01 \mathrm{mg} / \mathrm{L}$; manganese, $0.1 \pm 0.0 \mathrm{mg} / \mathrm{L}-0.04 \pm 0.01 \mathrm{mg} / \mathrm{L}$ and mercury, $0 \pm 0.0 \mathrm{mg} / \mathrm{L}$. The result showed that the stream is polluted with bacteria of public health importance and the stream water should be treated before use.
\end{abstract}

Key words: Microbiological, characteristics, Iyi-nna, stream, physicochemical, Nigeria

\section{Introduction}

Water of good drinking quality is of basic importance in human physiology and man's continued existence depends very much on its availability. The provision of portable water to the rural and urban population is necessary to prevent health hazards. Before water can be described to comply with certain physical, chemical and microbiological standards which are designed to ensure that the water is palatable and safe for drinking. Portable water is defined as water that is free from disease producing microorganisms and chemical substances deleterious to human (Ihekoronye and Ngoddy, 1985; FAO, 1997; Lamikara, 1999; Nikoladze and Akastal, 1999; Lemo, 2002).

Water can be obtained from stream, lakes, rivers, ponds, rain, spring and wells. Unfortunately clean pure water only exists briefly in nature and is immediately polluted by prevailing environmental factors, agricultural factors and human activities (Kolade, 1992; Raymond, 1992). The consequence of water borne bacteria and virus such as polio, hepatitis, cholera, typhoid, diarrhea and stomach cramps have been well established but nitrite contamination is just as deadly (Adamu, et al., 1991). Consequent to the realization of the potential health hazard that may result from contaminated drinking water, contamination of drinking water from any source is therefore of primary borne disease (Fapetu, 2000; Edema et al., 2001).

The original of source of any drinking water is rich in aquatic microbes, some of which could be dangerous if they enter the human body. Accordingly the treatment of water for drinking involves stages where microbes are removed or destroyed before the water is subjected to tests by Bacteriologists to ensure the safety for human consumption (Lamikara, 1999). Knowledge of the chemical qualities of water is necessary so as to guide its suitability of water for use. This physicochemical analysis of water at source must be carried out to determine or check the effective of treatment process (Nikoladze and Akastal, 1999).

Water related diseases continue to be one the major health problem globally. The high prevalence of diarrhea among children and infants can be traced to the use of unsafe water and unhygienic practices (Tortora et al., 2002). 
Water is one of the most essential needs for the continued existence of all living organism on earth. The day to day activities of all living organisms require water to whatever form. It is effectively and efficiently put in plants and animals, microorganisms and man (Sofola and Lawal, 1983). Within the cells, water is the medium for most chemical reactions. It makes up at least $5-95 \%$ of every cell and average $65-75 \%$ (APHA, 2002).

Water in nature is seldom totally pure. Rainfall is contaminated as it falls and the combustion of fossil fuel put sulphur compound responsible for acid precipitation in the air. The most dangerous form of water pollution occurs when faecal contaminants enter the water supply. Contaminants ingested through water cause many diseases such as typhoid fever, bacillary, cholera and other gastroenteritis caused by pathogens such Salmonella typhi, Shigella species, Vibrio cholerae and Escherichia coli (Tortola et al., 2002). Industrial and agricultural chemicals leached from the land enter the water in great amount and could be resistant to biodegradation. Apart from this, rural water often have excessive amount of nitrite from microbial action on agricultural fertilizers. When ingested, nitrite competes for oxygen in the blood.

Drinking water quality has always been a major issue in many countries especially in developing countries (Assembly of life Sciences, 1997). The World Health Organization in its guidelines for drinking water quality publication highlighted at least seventeen different and major genera of bacteria that may be found in surface water (WHO, 2006). The proportion of water borne disease outbreaks associated with the distribution system failures has been increasing over the years (Moe and Rheingans, 2006).

The aim of this work is to determine the microbiological and physicochemical characteristics of Umuariaga stream which is the source of drinking water for the community.

\section{Collection of the River Water Samples}

\section{Materials And Methods}

The steam water samples were collected from different stations along the stream. The samples for the microbial counts were collected in white plastic containers, which were previously sterilized with $70 \%$ alcohol and rinsed with distilled water. At the river side, the containers were rinsed twice with the river water before being used to collect the samples. Samples for dissolved oxygen (DO) and biochemical oxygen demand (BOD) were collected with clean brown bottles. The samples for the other physiochemical parameters were collected with $500 \mathrm{ml}$ sterile plastic containers. They were transported to the laboratory in an ice packed cooler and immediately analyzed on reaching the laboratory.

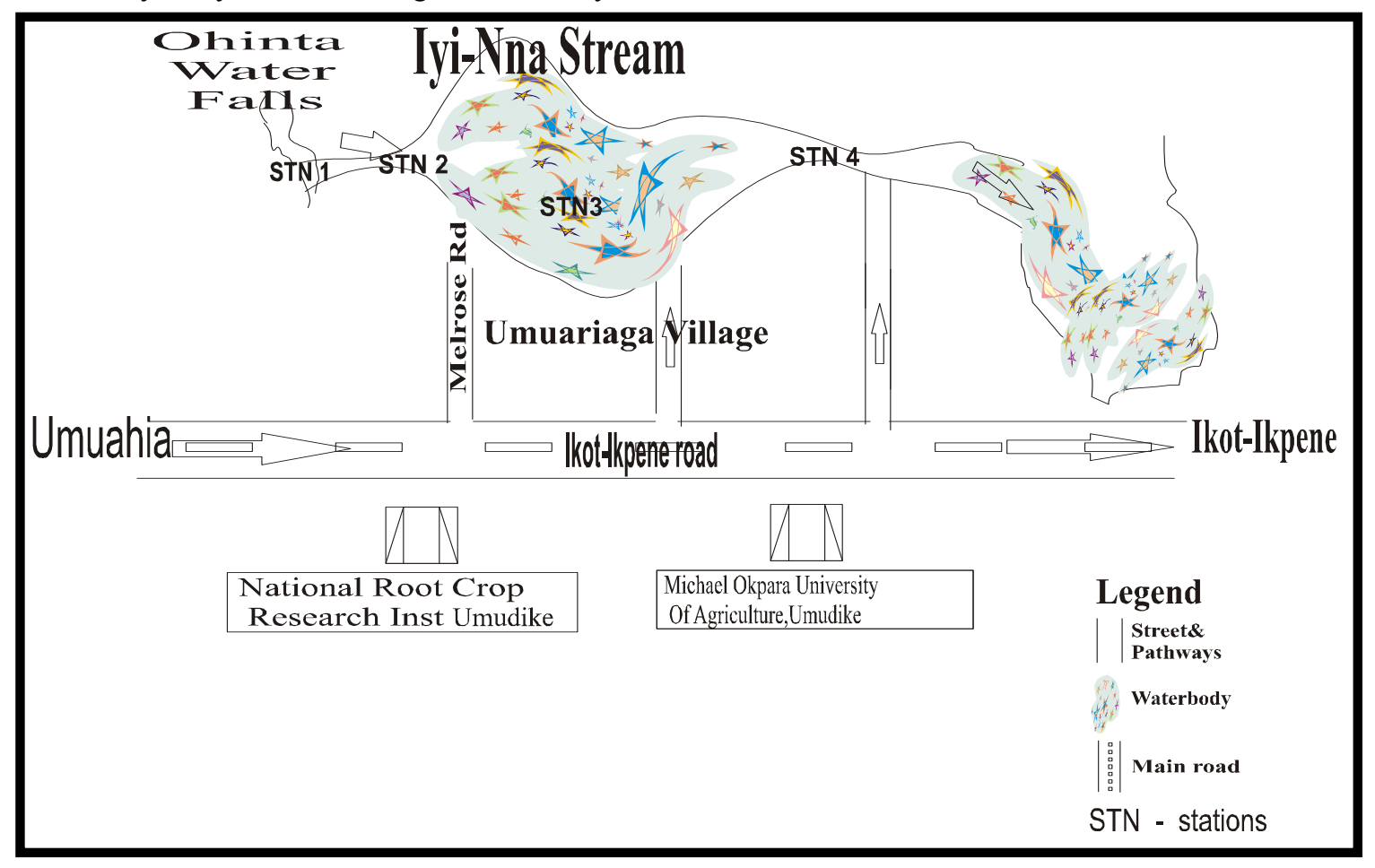

Fig.1: Map showing the Study Area 


\section{Chemical Reagents}

Chemical reagents used in the study were of analytical grade and were products of Hach Company, Colorado, USA; BDH Chemicals, Poole's, England and Sigma Chemical Company, St. Louis Missouri, USA. The microbiological media used were products of Oxoid and Difco Laboratories England. They were nutrient agar used for the estimation of total heterotrophic aerobic bacteria, purification and for stock culture; Sabouraud dextrose agar used for the isolation of fungi, Salmonella-Shigella agar for the isolation of Salmonella and Shigella, thiosulphate citrate bile sucrose agar for the isolation of Vibrio cholerae, eosin methylene blue agar for the isolation of Escherichia coli and MacConkey agar for coliform counts.

\section{Enumeration of Total Heterotrophic Bacteria and Fungi}

Samples of the stream water samples were serially diluted in ten folds. Total viable heterotrophic aerobic counts were determined using pour plate technique. Then the molten nutrient agar, MacConkey and Sabouraud dextrose agar at $45^{\circ} \mathrm{C}$ were poured into the Petri dishes containing $1 \mathrm{~mL}$ of the appropriate dilution for the isolation of the total heterotrophic bacteria and fungi and coliforms respectively. They were swirled to mix and colony counts were taken after incubating the plates at room temperature for $48 \mathrm{~h}$ and preserved by sub culturing the bacterial isolates into nutrient agar slants which were used for biochemical tests.

\section{Characterization and Identification of Bacterial and Fungal Isolates}

Bacterial isolates were characterized and identified after studying the Gram reaction as well as cell micro morphology. Other tests performed were spore formation, motility, oxidase and catalase production; citrate utilization, oxidative/fermentation $(\mathrm{O} / \mathrm{F})$ utilization of glucose; indole and coagulase production, starch hydrolysis, sugar fermentation, methyl red-Voges Proskaur reaction and urease production. The tests were performed according to the methods of (Cheesbrough, 2005; Adeoye, 2007; Agwung-Fobellah and Kemajou, 2007; Ochei and Kolhatkar, 2007). Microbial identification was performed using the keys provided in the Bergey's Manual of Determinative Bacteriology (1994).

Fungal isolates were examined microscopically using the needle mouth technique. Their identification was performed according to the scheme of Barnett and Hunter (1972) and Larone (1986).

\section{Physicochemical Parameters}

A number of physicochemical parameters of the stream water samples were determined. They included temperature, dissolved oxygen (DO), $\mathrm{pH}$, total dissolved solids (TDS), total suspended solids (TSS), turbidity, alkalinity and others were nitrate, phosphate, sulphate, biochemical oxygen demand (BOD) and chemical oxygen demand (COD). The $\mathrm{pH}$ was measured in-situ using Hach $\mathrm{pH}$ meter (Model EC1O); temperature and total dissolved solids were measured in-situ using Hach conductivity meter (Model CO150). The dissolved oxygen was also measured in-situ using Hach DO meter (Model DO175). Sulphate was determined using Barium chloride (Turbidimetric) method. Nitrate was determined using Cadmium reduction method. Alkalinity and phosphate were measured using potentiometric titration and Ascorbic acid methods respectively. Chemical oxygen demand and biochemical oxygen demand were determined using Walkley and Black dichromate reflux and Azide modification methods respectively. All analyses were in accordance with APHA (2005).

\section{Heavy Metal Analysis} Unicam).

The heavy metals were determined using Unicam atomic absorption spectrophotometer (Model 969,

\section{Results}

The results of the laboratory analysis of the water samples collected from different stations at the Iyinna stream water samples are shown in Tables $1-4$.

Table 1 shows the mean counts of the microorganisms isolated from the Iyi-nna stream water samples. The total aerobic plate count ranged from $1.5 \pm 0.2 \times 10^{6}$ to $1.12 \pm 0.5 \times 10^{7} \mathrm{cfu} / \mathrm{mL}$ while Salmonella- Shigella count ranged from $0 \pm 0.0 \mathrm{cfu} / \mathrm{mL}$ to $7 \pm 0.4 \times 10^{3} \mathrm{cfu} / \mathrm{mL}$, Vibrio cholerae count ranged from $0 \pm 0.0 \mathrm{cfu} / \mathrm{mL}$ to 6 $\pm 0.5 \times 10^{2} \mathrm{cfu} / \mathrm{mL}$ while Escherichia coli count ranged $0 \mathrm{cfu} / \mathrm{mL}$ to $2.4 \pm 0.6 \times 10^{3} \mathrm{cfu} / \mathrm{mL}$. The coliform count ranged from $0 \pm 0.0 \mathrm{MPN} / 100 \mathrm{~mL}$ to $902 \pm 20.0 \mathrm{MPN} / 100 \mathrm{~mL}$ while the fungal count ranged from $0 \pm 0.0 \mathrm{x}$ $10^{2} \mathrm{cfu} / \mathrm{mL}$ to $2.5 \pm 0.07 \mathrm{cfu} / \mathrm{mL}$. Statistically, $\mathrm{P}<0.05$ showed that there was significant difference in the mean counts for total aerobic plate count and fungal counts among the stations while $\mathrm{P}>0.05$ showed that there was no significant difference in the mean counts for Salmonella - Shigella count, Vibrio cholerae count and Escherichia coli count among the stations.

Table 2 shows the microorganisms isolated and their percentage occurrence. Pseudomonas species had the highest occurrence of $23.8 \%$ while the Vibrio cholerae and Salmonella species had the least occurrence of 
$2.4 \%$ for the bacterial isolates while for the fungal isolates, the Yeast species had the highest occurrence of $41.7 \%$ and Penicillium species had the least occurrence of $25 \%$.

The mean values of the physicochemical parameters of the stream water samples are shown in the Table 4. The mean values ranged as follows, $\mathrm{pH}, 6.15 \pm 0.1-6.90 \pm 0.2$; temperature, $29.0 \pm .02^{\circ} \mathrm{C}-31.0 \pm$ $0.05^{\circ} \mathrm{C}$; total dissolved solids, $0.024 \pm 0.002 \mathrm{mg} / \mathrm{L}-0.11 \pm 0.01 \mathrm{mg} / \mathrm{L}$; total suspended solids, $0.015 \pm$ $0.001 \mathrm{mg} / \mathrm{L}-0.034 \pm 0.003 \mathrm{mg} / \mathrm{L} ;$ alkalinity, $0.07 \pm 0.01 \mathrm{mg} / \mathrm{L}-0.36 \pm 0.03 \mathrm{mg} / \mathrm{L} ;$ hardness, $42.75 \pm 2.5 \mathrm{mg} / \mathrm{L}-$ $94.85 \pm 10.0 \mathrm{mg} / \mathrm{L}$; nitrate, $0 \pm 0.0 \mathrm{mg} / \mathrm{L}-65.47 \pm 5.0 \mathrm{mg} / \mathrm{L}$; sulphate, $0 \pm 0.0 \mathrm{mg} / \mathrm{L}-332.35 \pm 25.0 \mathrm{mg} / \mathrm{L}$; phosphate, $8.70 \pm 1.0 \mathrm{mg} / \mathrm{L}-86.82 \pm 7.5 \mathrm{mg} / \mathrm{L}$; zinc, $0.24 \pm 0.02 \mathrm{mg} / \mathrm{L}-1.88 \pm 0.3 \mathrm{mg} / \mathrm{L}$; iron, $0.86 \pm 0.01 \mathrm{mg} / \mathrm{L}$ $-3.54 \pm 0.05 \mathrm{mg} / \mathrm{L}$; copper, $0 \pm 0.0 \mathrm{mg} / \mathrm{L}-0.4 \pm 0.01 \mathrm{mg} / \mathrm{L}$; silver, $0 \pm 0.0 \mathrm{mg} / \mathrm{L}$; lead, $0 \pm 0.0 \mathrm{mg} / \mathrm{L}-0.8 \pm$ $0.01 \mathrm{mg} / \mathrm{L} ;$ manganese, $0.1 \pm 0.0 \mathrm{mg} / \mathrm{L}-0.04 \pm 0.01 \mathrm{mg} / \mathrm{L}$ and mercury, $0 \pm 0.0 \mathrm{mg} / \mathrm{L}$.

\section{Discussion}

The microbiological analysis reveals that the microbial load varied among the stations. Station one which is the spring had virtually the least or no counts in some of the microbial counts. The highest mean counts were recorded in station three due to domestic and human activities. However the bacterial load decreased downstream and this could be attributed to possible self purification and dilution of the pollutants (Nduka, 1995). The low fungal count may be attributed to the high $\mathrm{pH}$ of the water $(6.15-6.9)$, which generally discouraged fungal growth.

The bacteria isolated were Bacillus species, Escherichia coli, Pseudomonas species, Proteus species, Enterobacter species, Staphylococcus species, Shigella species and Vibrio cholerae. The presence of Escherichia coli, Enterobacter, Shigella and Vibrio cholerae in the water samples was seen as an indicator of possible contamination from faecal sources. The stream lays in a valley with elevated upland both sides. WHO (1998) reported the influence of water which include animal faeces into the water from neigbouring soil upland. This could explain the entrance of coliform into the stream. The high coliform count in station 3 could be due to human faeces from children's clothes being washed in the stream. Pseudomonas, Proteus, Bacillus and Staphylococcus are all ubiquitous inhabitants and as such are readily present in most environments including aquatic environment. This explains their predominance in the test water samples. It was also observed that the bacterial genera isolated consisted of mainly Gram negative species with only Bacillus and Staphylococcus species as the Gram positive species present.

The fungal isolates were identified to belong to the genera of Aspergillus, Penicillium and Yeasts. These fungal species are also ubiquitous inhabitants and could survive the relatively high $\mathrm{pH}$ of the water. Most fungi grow well in environment with low $\mathrm{pH}$ in the range of 5.0 \pm 0.4 (Pelczar, 1993).

The coliform values were high and therefore above the WHO drinking water limit of $0 \mathrm{MPN} / 100 \mathrm{~mL}$. The presence of coliforms is suggestive of human faecal contamination of the stream. This might be as a result of inadequate toilet system for the community where the stream is located, who traditionally defaecate near the bushes at the bank of the stream. The faecal materials might enter the stream through runoff as rainfall. Escherichia coli is not specifically confined to the human intestine. It is also present in the faeces of many domestic animals and birds and can be source of contamination of the stream. With the presence of these microorganisms of public health concern in the stream, it is clear that its water is unfit for human consumption and other domestic uses unless treated (Wilson and Dick, 1990; Amanchukwu, 1988).

The physicochemical parameters analyzed were all within the WHO limit for drinking water expect for hardness, nitrate, sulphate, lead and iron at certain stations. The mean values of sulphate at stations 3 and 4 were higher than WHO Limit of $250 \mathrm{mg} / \mathrm{L}$. The high values of sulphate in the water samples may be due to the application of sulphate containing detergents by the inhabitants of the community during washing activities. High sulphate levels have been implicated in the composition of some locally formulated detergents (Odokuma and Okpokwasili, 1992; Okpokwasili and Olisa, 1991).

The high values of nitrate at station 4 may be attributed to subsequent soil erosion and runoff during rainfall that contributes a significant proportion of these constituents into the stream (Izonfuo and Bariweni, 2001). It is reported that high nitrate values would lead to eutrophication of the stream. Phosphates and nitrates are important ingredients to the plant blooms and the eutrophication of lakes and streams (Kiely, 1993).

The iron and lead values being higher than the WHO drinking water limit at stations 3 and 2 respectively is an indication of the pollution of the stream from human activities. The water from the stream needs to be treated before being used for drinking and domestic purposes.

The high level of hardness at station 1 , which is the spring source may be attributed to the contact made by the rushing water on clay and stone surfaces while that of station 3 may be due to domestic waste influx into the water at that station.

It was observed that the water from the spring source was shown to be of good quality both microbiological and physicochemically. The parameters determined in this station were within WHO limit of drinking water. The water samples from the main body of the stream showed the presence of coliforms and 
other bacteria pathogenic to man. The presence of Escherichia coli, Salmonella, Shigella, Vibrio cholerae is of concern because they pose serious potential public health hazards thereby making the water unfit for consumption. The use of the stream water for domestic purposes such as washing, cooking and bathing should not be encouraged but should however be boiled or treated with cheap available water treatment method like water guards to enhance the safety of use. The water from the spring source is potable and should be consumed without much fear.

\section{Conclusion}

The result of the analysis showed that the water body is polluted. The stream water should therefore be adequately treated before consumption. There is the need for the inhabitant of the area to be properly educated on the dangers of contacting water- borne diseases from drinking contaminated water. They should also be advised on the need to stop indiscriminate waste disposal and other human activities such as defaecation at the river bank to stop further pollution of the river

\section{References}

[1] Adamu, M.M., Akinola, A.A., Alade, J.S. and Yamla, A.A. (1991). Water quality control in water and building sanitation, West African Health Examination Board, Laveniamum Press, Ibadan, pp 66 - 68

[2] Adeoye, A. (2007). Medical Laboratory Practice, $1^{\text {st }}$ edition FEMCO Publishers Limited, Lagos, Nigeria, p. 153

[3] Agwung-Fobellah, D. and Kemajou, S.T. (2007). Laboratory Microbiology and Activity Manual, Ark of Wisdom Publishers, Aba, Nigeria, pp. $12-37$.

[4] American Public Health Association (APHA). 2005. Standard Methods for Examination of Water and Wastewater, 20 ${ }^{\text {th }}$ edition, Washington, DC.

[5] Assembly of Life Sciences (1997).Drinking water and Health, National Academy of Sciences, U.S.

[6] Bergey's Manual of Determinative Bacteriology. (1994). $9^{\text {th }}$ edition, Holt, J.D. (Ed.), Williams Wilkins CO. Baltimore, p.783.

[7] Cheesbrough, M. (2005). District Laboratory Practice in Tropical Countries. Cambridge University Press, United Kingdom, pp. 30 41 .

[8] Edema, M.O., Omemu, A.M. and Fapetu, O.M. (2001). Microbiology and physicochemical analysis of different sources of drinking in Abeokuta, Nigeria, Nig. J. Microbiol.; 15(1): $57-61$.

[9] Food and Agricultural Organization FAO) (1997). Chemical Analysis Manual for Food and Water, $5^{\text {th }}$ edition, FAO Rome, 1: 20 36.

[10] Ihekoronye, A.I. and Ngoddy, P.O. (1985). Integrated Food Sciences and Technology for the Tropics; Macmillan Press London, Oxford, pp $95-195$.

[11] Izonfuo, L.W.A. and Bariweni, A.P. (2001). The effect of urban runoff water and human activities on some physicochemical parameters in the Epie creeks in the Niger Delta, Appl. Sci. Environ. Mgt.; 5(1): 47 - 55.

[12] Kiely, G. (1999).Environmental Engineering, International Edition, McGraw-Hill International Limited, London, UK

[13] Lamikara, A. (1999). Essential Microbiology for Students practitioners of Pharmacy, Medicine and Microbiology, $2^{\text {nd }}$ edition, Amkra Books, Lagos, pp 10 - 18

[14] Larone, B.H. (1986). Important Fungi: A Guide to Identification, Harper and Row Publishers, Hagerstown, Maryland, pp7 - 26.

[15] Moe, C. and Rheingans, R. (2006). Global challenges in water, sanitation and health, J. Water Health; 4: 41 - 57.

[16] Nduka, O. (1995). Microbial examination of water, aquatic and waste Microbiology, Enugu, Nigeria, pp107 - 109

[17] Nikoladze, G.D.M. and Akastal, S. (1999). Water Treatment for Public and Industrial Supply, MIR Publishers, Moscow, p163.

[18] Ochei, J.O. and Kolhatkar, A.A. (2008). Medical Laboratory Science: Theory and Practice, Tata McGraw-Hill Publishing Company Limited, New York, pp. $637-745$.

[19] Odokuma, L.O. and Okpokwasili, G.C. (1992). Role of composition of oil spill dispersants, Waste Manage.; $17: 491$ - 496

[20] Okpokwasili, G.C. and Olisa, A.O. (1990).Biodegradation of surfactants in liquid detergents and shampoo, Wat. Res.; 27: 1425 1429

[21] Pelczar, M.J., Chan, E.C.S. and Krieng, N.R.C. (1993). Microbiology, edition, Fong and Songs Printers Ltd Singapore, pp 56 - 65.

[22] Raymond, F. (1992). Le Problame dis can dans le monde (Problems of water), EB and Sons Ltd, UK; pp $123-126$.

[23] Sofola, F.O. and Lawal, M. (1983). Bacteriological analysis of water samples from main taps domestic water storage tanks in Metropolitan Lagos, Afri. J. Food Sci.; 6(3): 95 - 98.

[24] Tortola, J.G., Funke, R.B. and Case, L.C. (2002). Microbiology an Introduction, $7^{\text {th }}$ edition, Bibliography and Index Publishers, Daryl Fox; pp $258-260$.

[25] Wilson, P.A. and Dick, H.M. (1990). Topley and Wilson's Principle of Biotechnology, Virology and Immunity, $8^{\text {th }}$ edition, The Williams and Wilkin Company, Baltimore.

[26] World Health Organization (2006). Guideline for Drinking water, volume $1,3^{\text {rd }}$ edition, World Press, Switzerland

Table 1: The mean counts of the Microorganisms isolated from the Stream Water Samples

\begin{tabular}{llllll}
\hline & \multicolumn{5}{c}{$\mathbf{c f u} / \mathbf{m L}$} \\
\hline Station & TAPC & SSC & VC & EC & $\begin{array}{l}\text { CC } \\
\text { (MPN/100mL) }\end{array}$ \\
\hline 1 & $1.5 \pm 0.2 \times 10^{6}$ & $0 \pm 0.0$ & $0 \pm 0.0$ & $0 \pm 0.0$ & $0 \pm 0.0$ \\
2 & $3.7 \pm 0.5 \times 10^{6}$ & $2 \pm 0.2 \times 10^{3}$ & $0 \pm 0.0$ & $1.0 \pm 0.04 \times 10^{3}$ & $350 \pm 3.0$ \\
3 & $1.12 \pm 0.7 \times 10^{7}$ & $7 \pm 0.4 \times 10^{3}$ & $6 \pm 0.5 \times 10^{2}$ & $2.4 \pm 0.6 \times 10^{3}$ & $540 \pm 5.0$ \\
4 & $8.6 \pm 0.3 \times 10^{6}$ & $5 \pm 0.5 \times 10^{3}$ & $3 \pm 0.3 \times 10^{2}$ & $1.6 \pm 0.05 \times 10^{3}$ & $902 \pm 20$ \\
\hline
\end{tabular}

Legend: TAPC: Total aerobic bacterial plate count; SSC: Salmonella-Shigella count; VC: Vibrio cholerae count;

EC: Escherichia coli count; CC: Coliform count; FC: Fungal count 
Table 2: Microorganisms isolated from the Water Samples and their Percentage

Occurrence

\begin{tabular}{llc}
\hline Microorganism & Number of isolates & \% Occurrence \\
Bacteria & & 19.0 \\
Bacillus species & 16 & 15.5 \\
Enterobacter species & 13 & 11.9 \\
Escherichia coli & 10 & 4.8 \\
Proteus species & 4 & 23.8 \\
Pseudomonas species & 20 & 2.4 \\
Salmonella species & 2 & 3.6 \\
Shigella species & 3 & 16.7 \\
Staphylococcus aureus & 14 & 2.4 \\
Vibrio cholerae & 2 & 33.3 \\
Fungi & 8 & 25 \\
Aspergillus species & 6 & 41.7 \\
Penicillium species & 10 & \\
Yeast species & & \\
\hline
\end{tabular}

Table 3: The Mean values of the Physicochemical characteristics of the Stream Water Samples

\begin{tabular}{|c|c|c|c|c|c|}
\hline Parameter & Station 1 & Station 2 & Station 3 & Station 4 & $\begin{array}{l}\text { WHO } \\
\text { Limit }\end{array}$ \\
\hline Temperature $\left({ }^{\circ} \mathrm{C}\right)$ & $29.5 \pm 0.5$ & $29.5 \pm 0.3$ & $31.0 \pm 0.5$ & $29.0 \pm 0.2$ & \\
\hline $\mathrm{pH}$ & $6.90 \pm 0.2$ & $6.20 \pm 0.1$ & $6.15 \pm 0.3$ & $6.70 \pm 0.2$ & $6.0-8.0$ \\
\hline TDS (mg/L) & $0.027 \pm 0.001$ & $0.11 \pm 0.00$ & $0.024 \pm 0.002$ & $0.028 \pm 0.003$ & 50 \\
\hline TSS (mg/L) & $0.026 \pm 0.002$ & $0.015 \pm 0.001$ & $0.031 \pm 0.001$ & $0.034 \pm 0.003$ & 50 \\
\hline Alkalinity (mg/L) & $0.07 \pm 0.01$ & $0.33 \pm 0.03$ & $0.36 \pm 0.03$ & $0.26 \pm 0.02$ & \\
\hline Hardness $(\mathrm{mg} / \mathrm{L})$ & $94.85 \pm 10.0$ & $49.43 \pm 3.0$ & $65.47 \pm 5.0$ & $42.75 \pm 2.5$ & 50 \\
\hline $\mathrm{BOD}(\mathrm{mg} / \mathrm{L})$ & $0.10 \pm 0.0$ & $1.30 \pm 0.05$ & $2.27 \pm 0.2$ & $1.83 \pm 0.04$ & 3 \\
\hline Nitrate $(\mathrm{mg} / \mathrm{L})$ & $0 \pm 0.0$ & $14.05 \pm 2.0$ & $11.28 \pm 1.5$ & $65.47 \pm 5.0$ & 45 \\
\hline Phosphate (mg/L) & $8.70 \pm 1.0$ & $29.80 \pm 3.0$ & $86.82 \pm 7.5$ & $54.83 \pm 6.0$ & 200 \\
\hline Sulphate $(\mathrm{mg} / \mathrm{L})$ & $0 \pm 0.0$ & $232.09 \pm 15.0$ & $332.35 \pm 25.0$ & $274.67 \pm 20$ & 250 \\
\hline $\operatorname{Zinc}(\mathrm{mg} / \mathrm{L})$ & $0.24 \pm 0.02$ & $0.96 \pm 0.04$ & $1.88 \pm 0.3$ & $0.58 \pm 0.05$ & 3 \\
\hline Iron $(\mathrm{mg} / \mathrm{L})$ & $0.86 \pm 0.01$ & $1.34 \pm 0.03$ & $3.54 \pm 0.05$ & $2.42 \pm 0.01$ & 3 \\
\hline Copper (mg/L) & $0 \pm 0.0$ & $0.02 \pm 0.01$ & $0.04 \pm 0.01$ & $0.02 \pm 0.00$ & 0.05 \\
\hline Silver $(\mathrm{mg} / \mathrm{L})$ & $0.02 \pm 0.00$ & $0.02 \pm 0.0$ & $0 \pm 0.0$ & $0 . \pm 0.0$ & 0.05 \\
\hline Lead (mg/L) & $0 \pm 0.0$ & $0.08 \pm 0.02$ & $0.04 \pm 0.01$ & $0.04 \pm 0.01$ & 0.05 \\
\hline Manganese (mg/L) & $0.01 \pm 0.0$ & $0.03 \pm 0.01$ & $0.04 \pm 0.01$ & $0.02 \pm 0.0$ & 0.05 \\
\hline Mercury (mg/L) & $0 \pm 0.0$ & $0 \pm 0.0$ & $0 \pm 0.0$ & $0 \pm 0.0$ & 0.02 \\
\hline
\end{tabular}

